\title{
The Rural Child and the Ambivalence of Education in Zimbabwe: What Can Bricolage Do?
}

\author{
Bekithemba Dube*, Loyiso Jita \\ Faculty of Education, University of the Free State, Bloemfontein, South Africa
}

Received May 7, 2020; Revised July 7, 2020; Accepted July 20, 2020

\begin{abstract}
Cite This Paper in the following Citation Styles
(a): [1] Bekithemba Dube, Loyiso Jita , "The Rural Child and the Ambivalence of Education in Zimbabwe: What Can Bricolage Do?," Universal Journal of Educational Research, Vol. 8, No. 9, pp. 3873 - 3882, 2020. DOI: 10.13189/ujer.2020.080911.
\end{abstract}

(b): Bekithemba Dube, Loyiso Jita (2020). The Rural Child and the Ambivalence of Education in Zimbabwe: What Can Bricolage Do?. Universal Journal of Educational Research, 8(9), 3873- 3882. DOI: 10.13189/ujer.2020.080911.

Copyright $\subseteq 2020$ by authors, all rights reserved. Authors agree that this article remains permanently open access under the terms of the Creative Commons Attribution License 4.0 International License

\begin{abstract}
In this paper, we problematise post-colonial fragmentation and the exclusive approach to education. We focus on various trajectories faced by multigrade classes and propose bricolage as an expedient, doable and desirable approach to accommodating a variety of deprived learning and teaching realities. We couch this paper in bricolage because its agenda is taking a utilitarian approach to disposable resources, thereby enhancing teaching in rural multigrade classes. We used participatory action research as research methodology and centre the discussion within the confines of two questions: What are the trajectories of the postcolonial, exclusive curriculum in multigrade classes, and what can a bricolising pedagogy offer to mitigate these trajectories? We found that an exclusivist curriculum deprives rural students and teachers, in their quest to attain and provide quality education respectively. We argue that multigrade face critical challenges, which require inclusive education approach that values all children, despite geopolitical spaces.
\end{abstract}

Keywords Multigrade Class, Rural Schools, Bricolage, Participatory Action Research

\section{Introduction}

When postcolonial states, including Zimbabwe, gained their independence, many of them ushered in a new era of hope and anticipated a reversal of the ambivalence and ambiguity that had been associated with colonial rule.
Education became a priority of the Zimbabwean government and was premised within the Marxist-Leninist ideology of socialism. To this end, there was mass expansion of all sectors of education, including teacher education and primary and secondary schooling. While the innovation was desirable and doable, it was rather too ambitious, and not necessarily anchored in theory [1]. The expansion led to the introduction of multigrade classes, as a way to mitigate the ever-growing population and the need for education for all. Multigrade schools are geographically distanced from well-resourced learning sites, often in deprived communities, such as farms and rural areas. Thus, [2] gives another reason for the rise of multigrade classes, by arguing that they emerged as the dominant way of managing large numbers of students, who are organised into age divisions or classes. We agree with [3], who argues that, despite efforts by government, the urban-rural divide in education remains prominent. We are of the view that bricolage can help to close this gap, because bricolage is an effective approach for developing strategies of self-empowerment for application in subcultures, enterprises and institutions, and environments of scarcity [4].

This paper describes various studies that have been carried out in the area of mutligrade classes, and we show how this paper contributes to the ongoing narratives of multigrade classes. Reference [5] conducted a study that found that the multigrade class mode was imposed as a result of low pupil enrolments in the resettlement areas (that is, farm areas which were taken over from whites by the Zimbabwean government and redistributed among the 
general populace). However, this finding represents a simplistic approach to understanding the conundrum of the education system in Zimbabwe. The emergence of multigrade classes is influenced by a number of factors, not only low enrolment, such as unavailability of teachers and infrastructure. Reference [5] concludes the study by calling for the elimination of multigrade classes, which does not resonate well in the context of Zimbabwe, where shortages of teachers and infrastructure are common.

Reference [6], in a study on multigrade classes, argues that teachers in schools with such classes are overwhelmed with work and often "short-circuit" their teaching to achieve academic results that are pleasing, on paper, at least. In light of this, they suggest that schools with multigrade classes need to be prioritised regarding computerisation and other programmes aimed at making teaching and learning pleasurable, instead of laborious. While their proposal seems noble, it does not take into account the nature and underdevelopment of these multigrade schools, some of which lack even classrooms. So, for [6] to suggest computerisation as a solution under such circumstances is rather ambitious and does not contribute to resolving the challenges posed by multigrade classes.

Our criticism does not imply we downplay the role of computerisation, which is a hallmark of the $21^{\text {st }}$ century and of the fourth industrial revolution. However, we argue for the immediate utilisation of local and available resources to enhance teaching and learning, while such schools wait for computerisation to become a reality, which, in most mixed or multi-graded schools, is a utopia that they do not expect to experience in their lifetime.

Reference [7] conducted a study on multigrade classes, which they found to be characterised by a shortage of physical infrastructure and a poor financial resource base. To this end, they recommend that the school grading policy be reviewed, so that multigrade schools are categorised as special learning zones, and that a special revolving fund is allocated for financing teaching and learning processes. The suggestion to group multigrade schools in a cluster of special schools may seem practical but is not coherent with the idea of improving the lives of multigrade school students. Relegating these students to attend the category of special school implies that the students have barriers to learning, and this categorisation does not solve challenges faced by multigrade class. We are of the view this approach, of categorising schools with multigrade classes as special schools, would not address the problems students face in rural contexts.

In this light, our paper locates itself in the ongoing multigrade or rural education narrative by advocating a bricolage approach to learning, as advocated by the saying, when life gives you lemons, make lemonade. The problem under investigation is that rural schools, compared to city schools, continue to face teaching and learning difficulties due to lack of support from the government and Ministry of Primary and Secondary education, and that teachers are not capacitated to exploit local resources to address deprivations in rural learning contexts. Thus, a child in rural Zimbabwe is faced with complex problems, which needs problematisation by scholars and other education stakeholders, to construct better learning conditions under multiple deprivations. Informed by this problem, the aim of the study is to argue that it does not help if teachers, parents and students complain and blame the education department for multigrade schools; instead, we should focus on using the resources that are available in rural spaces. Furthermore, we explore ways in which available resources can contribute to effective and efficient teaching and learning in the context of deprivation and marginalisation of rural schools. The uniqueness of the study is that it taps into the transformative power of bricolage in teaching and learning, which unfortunately has not received sufficient attention in many developing countries such as Zimbabwe. Cognisant of this, the paper teases and unleashes the transformative power of bricolage in multigrade classes or rural schools [4], as an alternative learning strategy in schools that face multiple deprivations.

The paper unfolds as follows: First, we will define mutligrade class, discuss the theoretical framing of bricolage, and participatory action research (PAR), before discussing the data that was gathered.

\section{Definition of Multigrade Class}

Mixed classes comprise students from two different grade levels, being taught by one teacher in the same classroom [6]. According to [8], other, similar terms are multi-age or mixed-age, multistage, non-graded or ungraded, split, blended and combined classes, and vertical grouping and family grouping. Reference [6] concludes that, in Zimbabwe, multigrade classes are associated with poverty, grossly under-resourced schools, and schools built of poles, dagha [clay] and grass thatch a replica of rural schools. The phenomenon of multigrade classes is referred as in some contexts or countries as rural schools, which are allocated underdeveloped environmental spaces and are often deprived of quality education, compared to city schools [9-12]. Thus, the word multigrade and rural schools can be used interchangeably. It should be noted from the onset that the implication is that, while the study focused on Zimbabwe, the results resonate well with many African countries, such as South Africa, Malawi and Zambia, who face various similar trajectories relating to rural education.

\section{Theoretical Framing: Bricolage}

The paper is couched in bricolage, which is a theory within the transformative paradigm, which has as its agenda the full utilisation of resources to address unique 
contextual trajectories. Bricolage is a concept first considered by French anthropologist Claude Lévi-Strauss in 1967, as a part of his exploration of the nature of sense-making in some societies [13]. We believe bricolage is relevant for the forgotten rural child, because it advocates that people can construct something out of the little that is available, whether resources or systems, to achieve new goals [14-16]. Thus, people informed by bricolage use all available knowledge, of immediate interest or outdated, within or outside themselves, to solve a given problem [17].

Furthermore, bricolage refers to the processes by which people acquire objects from across social divisions, to create new cultural identities[4]. It is indeed true that forever-marginalised rural students and teachers in multigrade classes reimagine ways through which they can acquire new identities, and thereby break away from deprived learning conditions. We argue this way because bricolage allows the combining of resources and systems for new purposes, which serves as a mechanism to drive the discovery of innovations, which take the form of new "services" from existing resources[18,19]. All societies have natural resources, hence, the theory of bricolage calls for people to look beyond the ordinary, and harvest and explore natural resources for learning. Bricolage is convenient for this study, because it enables the adaptive design process that is necessary for resilience, and makes finding solutions to problems more achievable through use of critical resources or social systems [13]. Resilience that emerges from ordinary processes, such as locally available resources, offers a more optimistic outlook [20], is not expensive, and has the impetus to address the lived realities of rural multigrade students.

\section{Methodology: Participatory Action Research}

We chose PAR methodology with the understanding that the people who experience the problem are the people who can suggest the best solutions to their problems. Hence, this methodology involves active participation of the affected people in constructing their new identities, premised within the available resources. PAR was ideal for this paper, because, it "investigates the actual practices and not abstract practices and learning about the real, material, concrete, and particular practices of particular people in particular places"[21]. This approach is important, because multigrade-class students face unique experiences, conditions and challenges, which might not be addressed effectively by a blanket policy; however, exploiting resources that are available in their locality could ensure successful teaching and learning. Furthermore, this methodology is ideal for this study, because it "empowers the rights of those affected by a situation, and empowers people to set their own schemas for research and development, thereby giving them tenure over the process" [22]. To this end, the methodology strives, as suggested by [23], to challenge traditional ways of doing research. Its focus is on benefitting the community in which the research takes place. This is achieved through collaborative efforts that encourage reflection and the application of a problem-solving approach [24]. Through PAR, conditions of injustice are revealed and challenged [25], based on the capacity available. In short, PAR was the ideal methodology for this study, since it involves "community-oriented research and action for social change to promote marginalized communities, where the quest is to unearth the causes of social inequality" [26].

Our approach to PAR supports the reference to bricolage, since the attention is directed to processes, relationships, and interconnections among phenomena, with the intention of improving the human condition [27]. For this reason, by combining PAR and bricolage, we teased the muted research representations and, instead, adopted techniques from multiple perspectives, voices, and sources to address the challenges facing multigrade classes [28].

In implementing this methodology, we chose 15 studens, five teachers and 10 community members to participate; the latter included community leaders, parents, and education officers as a way to ensure reliability. Thus, in terms of reliability, we accepted the definition by [29] that considers reliability as an extent to which results are consistent over time and an accurate representation of the total population under study. The sample chose is a fair representation of the population, since it took account of various stakeholders in rural education in Zimbabwe, in accordance with PAR, which requires fair representation of those affected by the phenomenon under study [30]. To implement PAR informed by bricolage, we conducted focus group discussions that were guided by two research questions over a period of two weeks. In addition, we undertook six outings into the community to find resources that could be used by students and teachers to improve teaching and learning. Community participation enabled us to identify retired teachers with various skills, who could occasionally visit schools to assist in addressing trajectories related to multigrade classes. students became active in identifying various items that could be used to enhance the teaching of abstract concepts. The community engagement, through PAR, resonated well with bricolage - a theory that advocates for the effective use of local resources to change the human condition, in this case, multigrade classes, for the better. Because of time and financial constraints, the social media platform WhatsApp was used in this regard - it is reported to be an emerging way of doing research [31,32]. In terms of our research plan, we ensured that participants remained within the context of the questions, and in cases where they deviated from the questions, we reminded 
them to remain on topic, so as to remain focused and achieve the purpose of the study.

\section{Data Analysis and Ethical Considerations}

To analyse the data generated through PAR, it was subjected to the thematic approach suggested by [33], which comprises the following steps:

Step 1: Read and reread all the collected data. The data from focus group discussions was read and reread so that we could hear the views of the participants clearly.

Step 2: Draw up a preliminary list of themes arising from the data. Major issues and themes were identified and arranged according to the two main research questions of the study.

Step 3: Reread the data. Researchers checked if the identified themes matched what the participants had said and whether they related to the research questions.

Step 4: Link the themes to quotations and notes. The themes that had emerged from the data were linked to various scholarly views.

Step 5: Peruse the categories of themes to interpret them. During the interpretation of data, I remained cognisant of the research questions.

Step 6: Design a tool to assist to discern patterns in the data, in order to triangulate and determine the patterns during data analysis.

Step 7: Interpret the data and derive meaning. This step relates mainly to highlighting the research findings and arranging material according to categories that are premised on or guided by the research questions.

In order to meet the requirements of the principle of validity, we conducted member checking after analysing the data. In this stage of data processing, themes we had identified were discussed with the participants, to verify if the data responded to their lived experiences and the discussion and suggestions [34-36]. Validity is important, since participants involved in PAR are not treated as mere providers of information, but contribute to changing their life circumstances. We applied for ethical clearance from the University of the Free State (No. UFS-HSD2017/0998). Furthermore, we assured the participants that their identities would not be revealed, and we requested them to sign consent forms [37]. We made sure they understood that they could withdraw from the research at any time and that this data would be used to complement existing efforts to change teaching and learning conditions for the better in multigrade classes.

\section{Findings and Discussion}

The following section will discuss the findings informed by the research questions. It is important to note that, while these findings are based on the Zimbabwean context, they apply to many postcolonial countries that face challenges with rural education, which is characterised by underdevelopment and a lack of qualified teachers and access to resources [38,39]. The first finding is the lack of planning for multigrade classes.

\subsection{Lack of Planning for Multigrade Classes}

The trajectory that was raised by the participants is that the enacting of multigrade classes happened abruptly, mainly because classes fulfilled a political agenda, instead of an education agenda. According to [40], the "hastily instituted compulsory acquisition of land created a problem, namely, how to educate the children of the new farmers; hence, providing schools on the newly resettled farms had also to be fast-tracked". Due to this haste, inadequate structures and sites were identified and turned into schools. The assumption was that, as long there were teachers, learning could take place; little attention was paid to other factors that are essential for and conducive to successful education.

In a discussion with the co-researchers, Mzala, a schoolteacher, explained,

I was desperate for a job, and the only school that was available was a farm, I opted for the job only to discover that the school is just a shack, without resources, yet am expected to have good results.

A parent who attended the discussion said, Yes, we needed land and we were promised good schools here but due to shortage of classes, our students learn with other grades, I have never heard of this and I wonder how my Grade 4 learn with Grade 6. Is it vele [allowed]?

From the foregoing reports, it is clear that multigrade classes, as a by-product of political ideology, contributes to the underdevelopment of rural students, compared to their town counterparts. From a political space, the idea was to bring education closer to the resettled people, however, it created other challenges, and to undo this damage can take years. To address these challenges, the paper argues for a bricolage approach, as an immediate response to challenges of multigrade classes, while other options are being sought.

\subsection{Lack of Teacher Capacity in Multigrade Classes}

One of the problems that was identified in relation to multigrade classes is that few teachers are trained to teach mixed classes. In a discussion, $\mathrm{Mpu}$, a schoolteacher, reported,

As for me, I was new in a school, so the headmaster gave me the multigrade class since everyone refused the class. I was so clueless on what to do about in class.

Zuze, a school principal, confirmed Mpu’s experience, 
by explaining that,

As headmasters, our mandate is to make sure that the learning take place, as long students are in class under the supervision of the teacher, its fine with us but deep down we know we are unfair to teachers by giving them classes that they cannot teach, but the situation forces us. The truth is that no one is prepared to teach two or more classes under one roof yet paid for teaching one class.

The lack of training of teachers to teach multigrade classes poses a serious threat to the provision of quality education, especially for rural students. Reference [41] confirms this conclusion, by arguing that the establishment of multigrade schools placed new skills demands on some teachers, and, unfortunately, the teachers were not prepared for the new demands that came with the multigrade class. Informed by this argument, we agree with the observation made by [42], that,

curriculum writers, with all good intentions, have compiled volumes of well-conceived educational action plans, choosing specific materials and activities for their pre-conceived target, curriculum receivers, students, only to find that the curriculum users, teachers, are not prepared for the innovations.

Thus, Zimbabwe faces a serious challenge with regard to either initial teacher education, or in-service education - it is still failing to train teachers to deal with multigrade classes. This is our conclusion because the multigrade class has existed since independence in 1980, yet the teachers' college curriculum has not responded to the need to assist rural students who, by virtue of marginalisation - either economic or political - are still disadvantaged, and whose situation is being exacerbated by the curriculum.

\subsection{Umbrella Policies of Exclusion}

Another challenge caused by multigrade schools in Zimbabwe is that they suffer as a result of policies that are made at the centre, and which fail to cater for peripheral students in multigrade and rural contexts. One example of this centralised approach is the policy for information and communications technology (ICT). The ICT policy's objectives are to promote the development of ICT infrastructure, provide education and training programmes to produce knowledge workers and qualified human resources, to establish relevant structures and institutional mechanisms to promote ICT, and to encourage equitable access to ICT across genders and to youth, the elderly, and people with disabilities [43].

While the policy is promising and doable, the challenge is that, though the policy, in principle, seems to accommodate everyone, in praxis, it does not. Multigrade schools still struggle to access electricity, stable internet connections, computers and accessories to kickstart and implement ICT policy. During the discussion, Mzala explained that,

Multigrade class has many challenges and one of them is policies that favour town students over rural students, more so the multigrade class.

In support of this view, Nonki said that, Policies are failing us, for example, we are forced to teach ICT but we do not have the resources, and our students continue to fail examinations. The exam does not consider conditions which teacher and students operate under, such as lack of resources and multigrade class.

In light of these statements by the participants, we conclude that policy formulation is a serious challenge in postcolonial states, like Zimbabwe, since policy is not all-inclusive in principle, practice or resource allocation. To this end, the data indicates that, as long as policy is formulated to, technically, exclude the multigrade class, then students in this class will continue to underperform, despite other meaningful interventions being made. The findings correlates well with the study conducted by [44] within the South African context, which reports that rural students face various challenges, including exclusion. In this context of exclusion, informed by critical emancipatory theory, [44] was "opposed to any classroom practices that undermine the rights of rural students". Similarly, relating to the Zimbabwean context, exclusion of rural students by design or default must be challenged in every possible space, and part of addressing this challenge is to emancipate teachers and students, to bricolise the teaching and learning environment.

\subsection{Exclusion of Students in Lower Grades}

It was revealed during the research that teachers often ignore students in lower grades in the multigrade class. For example, if the multigrade class consists of studnets in Grades 4 to 6 , teachers will focus on Grade 6 and neglect the lower grades. While this may be unfair to students, the reality is that teachers cannot attend equally to all grades. The main challenge is that students in Grade 6 are not up to standard, because they had been overlooked in the previous years. The learning of students in lower grades is compromised. Julia, a participant, said that,

Most teachers tend to focus on the higher grade ignoring lower grade, thus, when the lower grade reach higher grade, they will have been left behind, but honestly, there is nothing teachers can do to change the situation.

Mzala added that,

Life with multigrade class is very difficult, due to resources and time fact, teachers are forced to focus on one group to maximize and prepare the students, besides we are paid for teaching one class, not three.

In spite of the challenges reported by the participates, we 
agree with [8] that, in the context of the deprivation regarding resources in rural areas, multigrade classes offer the only way of providing education in sparsely populated areas, or in more densely populated areas that are experiencing declining or shifting school enrolment rates. However, this does not mean we should not strive to improve the situation; it calls for a consistent fight, which is a reminder to the political elite that the lives of mutligrade class students matter, just as the lives of those in towns or privileged schools do. In essence, "multigrade students should participate to create a sense of direction, and ownership of learning [as opposed] to control and exercising authority" [45]. The students and teachers of multigrade classes can do so by embracing the bricolage approach, which will be discussed in the next section.

\section{Rethinking Learning in Multigrade Classes: Bricolising Education}

Affirming bricolage as an alternative to the trajectories faced by students in multigrade classes requires a change in the mindsets of teachers working in deprived areas. It will require a level of personal commitment, creativity, and responsiveness, rather than homogenous and mechanistic, action [46]. Thus, in the context deprived multigrade classes, bricolage is relevant as a possible solution, based on the notion that bricolage appreciates complex epistemological underpinnings and multiple perspectives [47], as long the goal is to change the circumstances of teachers and students and improve education using locally available resources to champion change. In addition, using bricolage as an approach to improve the situation of deprived multigrade classes has the potential to enable teachers, students, and education stakeholders to unleash their human power and potential to transform their otherwise transient situation [48]. In short, this approach is relevant, and is supported by [4], who argues that the idea that "bricolage is the 'second best' solution refers to its application in instances where there is a crisis, in resource-poor environments". Thus, the discussion below is shaped by the underlying philosophy of bricolage, which states that it is regime of activity, in which change and innovation are both creative and highly constrained, and in which individuals or groups create something new out of the resources they have at hand [49].

\subsection{Bricolaging the Environment}

Bricolaging the environment requires creative teachers; it requires teachers who understand the professional demands of the job, who are willing to go beyond the call of duty. Though we appreciate that many teachers in Zimbabwe, especially at multigrade schools, are facing difficulties in executing their jobs, they should not abandon creativity or working smart - these approaches ensure improved performance by students. Reference [50] suggests that professional teachers help students to develop the dispositions or attitudes associated with critical thinking, as well as the ability to think well. This advice is confirmed by [46], who asserts that teachers should apply an eclectic assemblage of skills, strategies and resources, which should be mediated through the school ethos, curricular demands, education policy and changing notions of professional standards and competence. The kind of teacher required by the multigrade class is one who can "make do by applying combinations of the resources at hand to new problems and opportunities" [51]. Reference [52] explains: "looking for not yet imagined tools, fashioning them with not yet imagined connections". In a discussion, Mzolo explained that,

You see, with teaching these days, one has to be very creative and use unthinkable things to bring knowledge to the classroom. For example, I see some teachers using games to teach mathematics and accounting concepts, but none creative teacher will sit and cry that the government is not giving me resources.

\section{Zama said,}

I have taught multi-grade class for 10 years and every year I am promised another teacher and resources and nothing of that nature is happening, thus, I must think outside the box for me to enjoy my work and use whatever I see useful for teaching. I have become a garbage collector for my students.

In summary, we agree with [19], that "becoming a bricoleur requires an understanding of and commitment to education that is concerned with society and its future". Toward this goal, the scholar-practitioner as bricoleur must continuously engage in learning new skills and acquiring new knowledge and methods, as well as continuously challenging old practices, knowledge and methods. This finding resonates with the observation by [53], that in dealing with rural schools and communities, one should not ignore what these capitals can contribute to ensuring that initiatives aimed at improving rural schools' are effective and sustained. Based on this observation, there is hope for the rural child, as long education stakeholders bricolise the environment towards constructing better learning environments in deprived contexts.

\subsection{Creating Multigrade Education Networks}

Another suggestion for improving education in multigrade classes is creating multigrade education networks. This suggestion resonates well with research by [54], which argues that education can improve in postcolonial countries when there is a network that cuts across different spaces and actors, towards construction of better learning environments. In this case, networks can be extended across districts, provinces and countries, since the 
phenomenon of multigrade classes is not limited to Zimbabwe. This network should include community members who can contribute resources in any capacity, to assist in the developmental aspects of education. In a discussion about networks, one parent suggested that,

We have retired teachers in our community, I am sure we can raise a little as parents and ask them to assist our children.

\section{Zama said,}

There are many youths that passed O Level here, they can be our local available resources, whereby we can ask them to assist with teaching lower grades, and raise something towards the upkeep.

In light of these proposals, it is clear that human resources is one of the assets that can be exploited to improve education in multigrade classes. This finding resonates with the observation by [55] that, when rural schools face challenges, the focus should be on strength-based paradigms, which emphasise the positive aspects that can be pursued to address deprivations, rather than always reinforcing the negatives. Informed with the foregoing, we agree with [56], who argue that bricolage enables students and teachers to "stock" resources and develop intimacy with "what is at hand". While teachers waits for government to provide resources - which might not happen - the multigrade schools can harness human resources available locally, and negotiate a fee to pay such contributors. The community can do something to assist schools. During a discussion, Dlodlo, a community member, said that,

My son had a chicken egg brooder which he was not using since he is overseas, then the headmaster approached me and I liaised with my son, who agreed that the school can use it, now that school is keeping chickens to feed both teachers and students.

To build networks, schools must have good relationships with families in the community. In Dlodlo's case, the family was willing to assist to help the school - this is bricolage in action. Instead of teachers and students begging government to improve their conditions, teachers, assisted by the community, can bricolage their environment, which will result in improving the pass rate of students in multigrade classes. Thus, for successful bricolage in multigrade schools, there is need, as suggested by [52], for a continued "searching for the nodes, the nexuses, the linkages, the interconnections, the fragile bonds between disciplines, between bodies of knowledge and partners”. This approach, as proposed by [57], ignites an inclusive approach that is purposeful and builds commitment towards positive change and better learning conditions, especially in rural contexts.

\subsection{Policy Networks for Multigrade Classes}

Informed by bricolage thinking, the study recommends creating policy networks for multigrade classes, and with curriculum planners and policy makers. Policy networks will allow the voices of the stakeholders of multigrade schools to be heard and factored in when policies that affect rural students are designed. It is our view that policy networks will assist curriculum planners to design curriculum packages that are tailor-made to cater for different strategies used by people in multiple deprivation learning contexts. It does not take much to realise that a one-size-fits-all curriculum will not work for the Zimbabwean context, thus, a decentralised form of schooling that takes into consideration different deprivations should be mooted, and policy networks is a good starting point. To achieve this, there is need for Zimbabwe to tap into policies from other countries, such as Poland, where rural education has improved significantly[58]. It is our submission that the realities faced by students and educators need a policy network that makes it possible to adopt best practices in international contexts to improve education in rural or multigrade contexts.

\section{Relevance of the Study in the International Contexts}

The challenges discussed here are not peculiar to the Zimbabwean context but are visible in many African countries, and beyond[59-61]. Cognisant of this, the results and recommendations of the study can be used to address various trajectories faced by rural children in multigrade classes; it also resonates with the principle of generalisability in research, where results in one context can be used in a different context to achieve same results, which, in this case, is improving education in rural contexts[62]. It is important to have this approach so that countries can share best practices among educators, to enact structures and systems to the advantage of rural students. Problems of education problems in Zimbabwe, or any other country, cannot be solved in isolation, but through collaboration and networking[63] of different actors and stakeholders, to construct better learning conditions for rural students. The work ignites the need for rural and multigrade schools to work together despite different geographical spaces. Bricolage, as used in this paper, has the impetus to contribute to transform rural schools, as long teachers and students become creative and construct better conditions despite deprivations. As we were completing this research, we referred to scholars from Zimbabwean and other countries to suggest ways in which education in rural contexts could be enhanced. This confirms that Zimbabwe is not an isolated case, but can work within a framework and theories, such as bricolage, that have been used elsewhere.

The limitation of this research is that bricolising education cannot be started at school level but should be 
infused at the time of initial teacher education so that teachers are equipped to use the best in their environment to enhance teaching and learning. It is based on this limitation that I recommend that bricolage should be one of the theories that frame teacher education in Zimbabwe, and beyond, to empower teachers to use their environment effectively to enhance teaching and learning.

\section{Conclusions}

In this paper, we problematised and pointed out the challenges faced by multigrade school students and educators. In light of the challenges and the urgent need to assist students in deprived contexts, we proposed bricolage as a theory and an approach that could be used to mitigate the challenges facing teaching and learning. The paper argues that bricolaging the learning environment is doable and desirable, and is an immediately available approach to assist students and educators in multigrade or rural schools. The paper argued that there is a need for policy networks, and for curriculum and policy negotiation, as an alternative, to cater for the needs of deprived students. The paper also pointed out the relevance of this paper to the international community, where similar trajectories concerning education in rural contexts may be experienced. We ended the paper by highlighting the limitation of the study, thereby igniting the need for further research to ensure rural children are emancipated through local resources to learn despite multiple deprivations, and bricolage theory offers such emancipation.

\section{REFERENCES}

[1] G. Y. Kanyongo. Zimbabwe’s Public Education System Reforms: Successes and Challenges, International Education Journal, Vol. 6, No. 1, 65-74. 2005.

[2] S. Veenman. Cognitive and Non-Cognitive Effects of Multi-Age Classes. A Best Evidence Synthesis, Review of Educational Research, Vol. 65, No. 4, 1-15, 1995.

[3] S. I. Chingombe, W. Chitumba. A Survey of Opinions of Major Stakeholders Regarding the Feasibility and Necessity for the Hearing Impaired Child to Speak, International Journal Science and Research Vol. 2, No. 8, 136-140. 2013.

[4] J. I. Phillimore, R. Humphries, F. Klaas, M. Knecht. Bricolage: Potential as a conceptual Tool for Understanding Access to Welfare in Superdiverse Neighbourhoods, IRIS Working Paper Series, No. 14/2016, Institute for Research into Superdiversity, University of Birmingham, 2016.

[5] N. Machemedze, E. Chinamasa. Primary School Composite Class Teaching and Learning Mode: Views of Some Stakeholders, Zimbabwe Journal of Educational Research, Vol. 27, No. 3, 455-484, 2015.

[6] T. Nyoni, N. Nyoni. Composite Classes: The Murezi School
Experience, International Journal of Education Administration and Policy Studies, Vol. 4, No. 2, 70-77, 2012.

[7] T. Dondofema, W. Samkange. Challenges Faced by Primary School Teachers in Schools with Multi-Grade Classes in Zimbabwe: A Case for Ten Primary Schools in Gutu District in Masvingo Province of Zimbabwe, Scholars Journal of Arts, Humanities and Social Sciences, Vol. 4, No. 7, 758-76, 2016.

[8] S. J. Wilson, M. W. Lipsey, J. H. Derzon. The Effects of School-Based Intervention Programs on Aggressive and Disruptive Behavior: A Meta-Analysis, Journal of Consulting and Clinical Psychology, Vol. 71, 136-149, 2003.

[9] T. Nkambule, R. Balfour, G. Pillay, R. Moletsane. Rurality and Rural Education: Discourses Underpinning Rurality and Rural Education Research in South African Postgraduate Education Research 1994-2004, South African Journal of Higher Education, Vol. 25, No. 2, 341357, 2011.

[10] [A. Gordon, W. Qiang. Education in Rural Areas of China and South Africa: Comparative Perspectives on Policy and Educational Management, UNESCO International Research and Training Centre for Rural Education, Nanjing, 2002.

[11] P. E. Myende, V. Chikoko. School-University Partnership in a South African Rural Context: Possibilities for an Asset-based Approach. Journal of Human Ecology, Vol. 46, No 3, 249-259, 2014.

[12] M. Gardiner. Education in the Rural Areas: Issues in Education Policy No 4. Centre for Education Policy Development, Johannesburg, 2008.

[13] J. Vanevenhoven, D. Winkel, D. Malewicki, W. L. Dougan, J. Bronson. Varieties of Bricolage and the Process of Entrepreneurship, New England Journal of Entrepreneurship, Vol. 14, No. 2, 53-66, 2011.

[14] M. Aagard. Bricolage: Making Do With What is at Hand, Creative Nursing, Vol. 15, No. 2, 82-84, 2009.

[15] M. G. Mahlomaholo. Design Research Towards the Creation of Sustainable Postgraduate Learning Environments, 6th International Proceedings of Conference of Education, Research and Innovation, 18-20 November, Seville, Spain, 4614-4623, 2013.

[16] J. P. Scribner. The Problems of Practice: Bricolage as a Metaphor for Teachers' Work and Learning, Alberta Journal of Educational Research, Vol. 51, No. 4, 295-310, 2005.

[17] P. Louridas. Design as Bricolage: Anthropology Meets Design Thinking, Design Studies, Vol. 20, No. 6, 517-535, 1999.

[18] R. Duymedjian, C. C. Rüling. Towards a Foundation of Bricolage in Organization and Management Theory, Organization Studies, Vol. 31, No. 2, 133-151, 2010.

[19] M. J. Jenlick. The School Leader as Bricoleur: Developing Scholarly Practitioners for Our Schools, NCPEA Education Leadership Review, Vol. 7, No. 2, 1-12, 2007.

[20] Masten, A. S. Ordinary Magic. Resilience Processes in 
Development, American Psychologist, Vol. 53, No. 3, 227 238, 2001.

[21] S. Kemmis, R. McTaggart. Communicative Action and the Public Sphere. In N. K. Denzin, Y. S. Lincoln (Eds.), The Sage handbook of qualitative research (pp. 559-603), Sage, Thousand Oaks, CA, 2007.

[22] A. Cornwall, R. Jewkes. What is participatory action research? Social Science and Medicine, Vol. 41, 1666-1676, 1995.

[23] L. K. Lopez. A Media Campaign for Ourselves: Building Organisational Capacity Through Participatory Action Research, Journal of Media Practice, Vol. 16, 228-224, 2015.

[24] M. D. Tshelane. Participatory Action Research and Construction of Academic Identity Among Postgraduate Research Students, The Journal of Transdisciplinary Research in South Africa, Vol. 9, 413-29, 2013)..

[25] R. Loewenson, A. C. Laurell, C. Hogstedt, L. D’Ambruoso, Z. Shroff. Participatory Action Research in Health Systems: A Methods Reader, TARSC, AHPSR, WHO, IDRC Canada, EQUINET, Harare, 2014)

[26] [B. T. Williams, M. Brydon-Miller. Changing Directions: Participatory Action Research, Agency, and Representation. In S. G. Brown, S. I. Dobrin (Eds.), Ethnography Unbound: From Theory Shock to Critical Praxis (pp. 241-57), State University of New York Press, Albany, 2004.

[27] J. L. Kincheloe. On the Next Level: Continuing the Conceptualizations of Bricolage, Qualitative Inquiry, Vol. 11, No. 3, 323-350, 2005

[28] Y. Rogers. HCI Theory: Classical, Modern, and Contemporary, Synthesis Lectures on Human-Centered Informatics, Vol. 5, 1-129, 2012.

[29] M. Joppe 2000. The Research Process. Retrieved February 25, 2020, from http://www.ryerson.ca/ mjoppe/rp.htm

[30] M. Titterton, H. Smart. Can Participatory Research be a Route to Empowerment? A Case Study of a Disadvantaged Scottish Community, Community Development Journal, Vol. 43, No. 1, 52-64, 2008.

[31] Department for Work and Pensions. The Use of Social Media for Research and Analysis: A Feasibility Study, Oxford Internet Institute, Oxford, 2014.

[32] M. A. Reeve, M. Partridge. The Use of Social Media to Combat Research Isolation, Annals of the Entomological Society of America, Vol. 110, No. 5, 449-456, 2017. https://dx.doi.org/10.1093/aesa/sax051

[33] S. Laws, C. Harper, R. Marcus, R. Research for Development, Sage, London, 2003.

[34] L. Birt, S. Scott, D. Cavers, C. Campbell, F. Walter. Member Checking: A Tool to Enhance Trustworthiness or Merely a Nod to Validation, Qualitative Health Research, Vol. 26, No. 12, 1802-1811, 2016). https://doi.org/10.1177/104973 2316654870

[35] B. Bygstad, B. E. Munkvold. The Significance of Member Checking Validation in Qualitative Analysis: Experiences from a Longitudinal Case Study. Proceedings of the 40th Hawaii International Conference on System Sciences, 2007 https://core.ac.uk/download/pdf/52058218.pdf

[36] J. Gunawan. Ensuring Trustworthiness in Qualitative Research, Belitung Nursing Journal, Vol. 1, No. 1, 10-11, 2015.

http://belitungraya.org/BRP/index.php/bnj/article/viewFile /4/pdf

[37] K. Fritz. Ethical Issues in Qualitative Research, Bloomberg, Johns Hopkins University, 2008.

[38] E. Cristobal-Fransi, Y. Montegut-Salla, B. Ferrer-Rosell, N. Daries. Rural Cooperatives in the Digital Age: An Analysis of the Internet Presence and Degree of Maturity of Agri-Food Cooperatives' Ecommerce, Journal of Rural Studies, Vol. 74, 55-66, 2020. https://doi.org/10.1016/j.jru rstud.2019.11.011

[39] D. Hlalele. Social Justice and Rural Education in South Africa, Perspectives in Education, Vol. 30, No. 1, 111-118, 2012.

[40] P. J. Mavhunga, C. Mazodze. Quality of Educational Provision in Fast Track Resettlement Schools in Zimbabwe: A Case Study of Chiwodza Primary School, European Scientific Journal, Vol. 1, 438-448, 2014.

[41] O.Mavundutse, C. Munetsi, A. Mamvuto, P. J. Mavhunga, P. Kangai, R. Gatsi. Emerging Teacher Education Needs as a Result of Land Reform in Zimbabwe: A Focus on New Resettlement Areas, Academic Research International, Vol. 3, No. 2, 298-305, 2012.

[42] M. Schwartz. For Whom do We Write the Curriculum? Journal of Curriculum Studies, Vol. 38, No. 4, 449-457, 2006. https://doi.org/10.1080/00220270500296606

[43] S. Isaacs. Survey of ICT and Education in Africa: Zimbabwe Country Report. InfoDev ICT and Education Series, World Bank, Washington, DC, 2007. http://documents.worldbank .org/curated/en/377851468007810842/Survey-of-ICT-andeducation-in-Africa-Zimbabwe-country-report

[44] M. M. Nkoane. Critical Liberatory, Inclusive Pedagogy: Arguing for a Zero Defect, Acta Academica, Vol. 43, No. 4, 111-126, 2010.

[45] J.-L.Denis, A. Langley, V. Sergi. Leadership in the Plural, The Academy of Management Annals, Vol. 6, No. 1, 211283, 2012. https://doi.org/10.1080/19416520.2012.667612

[46] L. Campbell. Pedagogical Bricolage and Teacher Agency: Towards a Culture of Creative Professionalism, Educational Philosophy and Theory, Vol. 51, No. 1, 31-40, 2018.

[47] M. S. Mosia, Periodisation of Mathematics Teacher Knowledge for Teaching: A Construction of Bricolage, Southern African Review of Education, Vol. 22: 134-151, 2016.

[48] Mahlomaholo, S. G. Naivety of Empiricism Versus Complexity of Bricolage in Creating Sustainable Learning Environments, Proceedings of International Conference of Education, Research and Innovation, 18-20 November 2013, Seville, Spain, 2013.

[49] Louvel, S. Understanding Change in Higher Education as Bricolage: How Academics Engage in Curriculum Change, Higher Education, Vol. 66, No. 6, 669-691, 2013. 
[50] K. Lombard, M. Grosser. Critical Thinking: Are the Ideals of OBE Failing us or are We Failing the Ideals of OBE? South African Journal of Education, Vol. 28, 561-579, 2008.

[51] T. Baker, R. E. Nelson. Creating Something From Nothing: Resource Construction Through Entrepreneurial Bricolage, Administrative Science Quarterly, Vol. 50, No. 3, 329-366, 2005.

[52] Y. S. Lincoln. An Emerging New Bricoleur: Promises and Possibilities - A Reaction to Joe Kincheloe's "Describing the Bricoleur”, Qualitative Inquiry, Vol. 7, 693-696, 2001.

[53] M. Myende, D. Hlalele. Framing sustainable rural learning ecologies: A case for strength-based approaches. Africa Education Review, Vol. 15, No 1, 1-17

[54] N. Moyo, M. Modiba. Government and Educational Reform: Policy Networks in Policy-Making in Zimbabwe, 1980 2008, Journal of Education Policy, Vol. 28, 371-385, 2013.

[55] R. Moletsane. Repositioning Educational Research on Rurality and Rural Education in South Africa: Beyond Deficit Paradigms, Perspectives in Education, Vol. 30, No. 1, 1-8, 2012.

[56] S. Linstead, R. Grafton-Small Organization Bricolage. In B. A. Turner (Ed.), Organizational Symbolism (pp. 291-309), De Gruyter, Berlin, 1990.

[57] S. R. Komives, N. Lucas, T. R. McMahon. Exploring leadership: For College Students Who Want to Make a
Difference, Jossey-Bass, San Francisco, 2013.

[58] A. Levitas, S. Golinowska, J. Herczyński. Improving Rural Education in Poland. Report Prepared for the Warsaw Delegation of the European Commission by the CASE Foundation, 2001. Available at https://case-research.eu/file s/?id_plik=3622

[59] D. Y. Dzansi, K. Amedzo. Integrating ICT into Rural South African Schools: Possible Solutions for Challenges, International Journal of Education Science, Vol. 6, No. 2, 341-348, 2014.

[60] K. Mohangi, S. Krog, O. Stephens, N. Nel. Contextual Challenges in Early Literacy Teaching and Learning in Grade R Rural Schools in South Africa, Per Linguam, Vol. 32, No. 1, 71-87, 2016.

[61] Alliance for Excellent Education. Current Challenges and Opportunities in Preparing Rural High School Students for Success in College and Careers: What Federal Policymakers Need to Know. Alliance for Excellent Education, Washington, 2010.

[62] J. Øvretveit, L. Leviton, G. Parry. Increasing the Generalisability of Improvement Research with an Improvement Replication Programme, BMJ Quality \& Safety, Vol. 2011, No. 20, 87-91, 2011.

[63] Pont, B., Nusche, D., \& Moorman, H. Improving School Leadership: Policy and practice, OECD, 2008. Available at http://www.oecd.org/education/school/44374889.pdf 